\title{
『環境配慮型曳船(ハイブリッドタグボートシステム)の開発』 Marine Engineering of the Year 2013 を受賞*
}

\section{三 村 治 夫**}

Marine Engineering of the Year は, マリンエンジ ニアリング分野の十分に優れた技術開発成果を表彰す ることによって, その先進性・独創性を広く国内外に 発信し, 関連する技術をより発展させることを目的に 制定されています。この表彰は2004 年から毎年行わ れています。

2013 年もこれまで同様に, 学会賞等審査委員会で応 募案件を厳正かつ慎重に審査し, 新潟原動機株式会社, 株式会社 IHI，日本郵船株式会社，株式会社ウイング マリタイムサービス, 京浜ドック株式会社, 一般財団 法人日本海事協会の 6 者が共同開発した「環境配慮型 曳船（ハイブリッドタグボートシステム）の開発」を 選出しました. 本件は理事会に上程され, 正式に決定 しました.

ハイブリッドタグボートシステムは国産初のプラグ インハイブリッド推進システムとして開発され, タグ ボート搭載は世界で 4 例目です (図 1). 運用時 $30 \%$ 以 上の燃料消費量削減， $27 \%$ の $\mathrm{CO}_{2}$ 排出量削減（充電時 の陸電 $\mathrm{CO}_{2}$ を含む)，30\%の $\mathrm{NOx}$ 排出量削減を実証し ています. 加えて, モータ使用時の騒音は同速度の既 存システム比で $20 \%$ 低減しています. 当該システムの 大気環境負荷の低減及び省エネルギ一性能は卓越して おり，このような舶用ハイブリッドシステムを開発し たことが授賞理由の重要な部分に該当します.さらに, 本システムは主機関とモータ，ディーゼル然料とリチ ウムイオン電池という推進系の圥長性を活かし, 負荷 変動に追従できる高い性能を有しています. タグボー 卜は船体に対して相対的に出力が大きい推進用主機関 を有していますが，稼働時間の多くは低負荷運転で使 用されています. 推進システムの高効率化と実際の運 転状況を考慮すると, 低負荷時に電気推進へ切り替え ることができるハイブリットシステムの導入は, タグ ボート運航の特殊性と整合した技術開発と言えます。

実際の運用で実証した省エネルギー性能及び $\mathrm{CO}_{2}$ や NOx の削減効果のみならず, リチウムイオン電池 を搭載した初のハイブリッド推進船として, 安全性評 価や法令策定のモデルとなったことも, 授賞理由に挙

*原稿受付 平成 26 年 4 月 25 日.

**正会員 神戸大学大学院海事科学研究科 (神戸市東灘区深 江南町 5-1-1).
げることができます。

本船（「翼」(256 トン))は，一般財団法人日本海事 協会の「業界要望による共同研究」支援を受け，京浜 ドック (株) が建造し，2013 年 3 月に横浜港に就航し ました，現在，(株）ウィングマリタイムサービスが本 船を運航しています.

本研究成果は，上海で 2013 年に開催された国際会 議 CIMAC 2013 において, Development of the hybrid tugboat system (Paper No. 138) と題して発 表されています。先進技術が国際会議で発表されたこ とで，舶用ハイブリッドシステムの開発が加速し，よ り信頼性の高い完全・安心な推進システムの開発につ ながると考えられます，総じて，本件はタグボート運 航の特殊性に適合したハイブリッド推進システムの開 発をとおし，省エネルギ一運航を基盤とした経済性の 高い船舶運航の実現へと研究が進展する基礎を築いた 優れた成果であると評価しました。

本件は，国土交通省の後援により，本年 7 月開催の 海事工学関連学会合同表彰式において表彰されます.

(第 49 期 学会賞等審査委員会委員長)

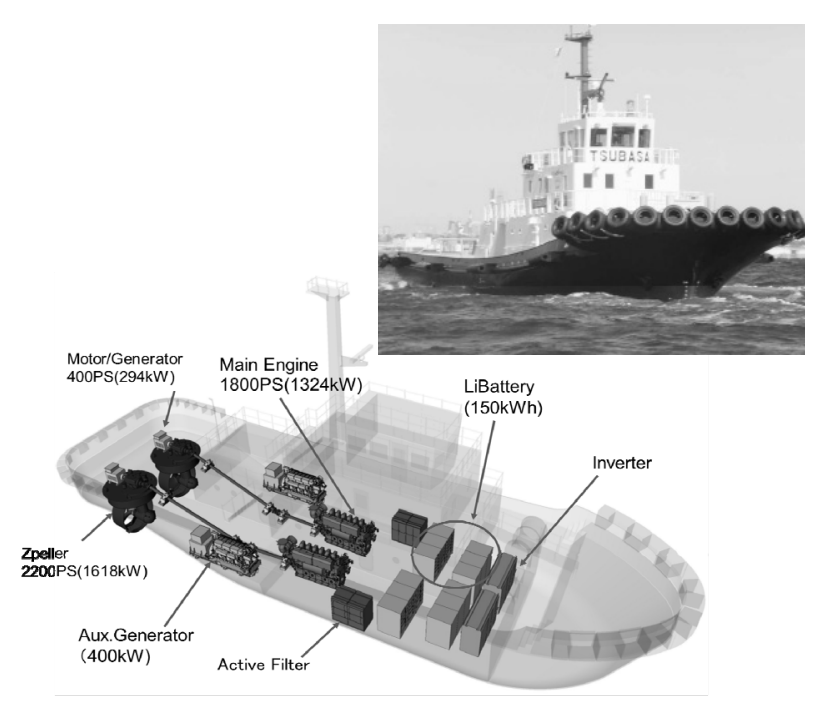

図 1 ハイブリッドタグボートシステムの 3D レイアウト と本システムを搭載した「翼」全景 